Research Paper

\title{
Tanshinone IIA Inhibits $\beta$-Catenin Nuclear Translocation and IGF-2R Activation via Estrogen Receptors to Suppress Angiotensin II-Induced H9c2 Cardiomyoblast Cell Apoptosis
}

\author{
1. Graduate Institute of Basic Medical Science, China Medical University, Taichung 40402, Taiwan; \\ 2. Department of Obstetrics and Gynecology, Taichung Veteran's General Hospital, Taichung 40705,Taiwan \\ . Department of Nursing, MeiHo University, Pingtung 91202, Taiwan; \\ Section of Cardiology, Yuan Rung Hospital, Yuanlin, Taiwan; \\ 5Institute of Oral Sciences, College of Oral Medicine, Chung Shan Medical University, Taichung40201, Taiwan; \\ Department of Family Medicine, China Medical University Hospital, Taichung, Taiwan; \\ School of Medicine, College of Medicine, China Medical University, Taichung, Taiwan; \\ Department of Surgery, School of Medicine, College of Medicine, Taipei Medical University, Taipei11031, Taiwan; \\ Department of Biotechnology, Bharathiar University, Coimbatore-641 046, India; \\ 10. Department of Biological Science and Technology, China Medical University, Taichung 40402,Taiwan; \\ 11. Department of Health and Nutrition Biotechnology, Asia University, Taichung 41354, Taiwan; \\ 12. School of Chinese Medicine, China Medical University, Taichung 40402, Taiwan.
}

Ya-Fang Chen, 2, Cecilia Hsuan Day³, Nien-Hung Lee, Yu-Feng Chen", Jaw-Ji Yang5, Chih-Hsueh Lin ${ }^{6,7}$, Ray-Jade Chen ${ }^{8}$, Peramaiyan Rajendran ${ }^{1}$, Vijaya Padma Viswanadha ${ }^{9}$, Chih-Yang Huang1,11,12匹

$\triangle$ Corresponding author: Chih-Yang Huang PhD Address: Graduate Institute of Basic Medical Science, Graduate Institute of Chinese Medical Science, China Medical University and Hospital, No. 91, Hsueh-Shih Road, Taichung 40402, Taiwan Phone number: 886-4-2205-3366 ext. 3313 FAX number: 886-4-2207-0465 Email: cyhuang@mail.cmu.edu.tw

(c) Ivyspring International Publisher. This is an open access article distributed under the terms of the Creative Commons Attribution (CC BY-NC) license (https://creativecommons.org/licenses/by-nc/4.0/). See http://ivyspring.com/terms for full terms and conditions.

Received: 2017.04.03; Accepted: 2017.09.01; Published: 2017.09.30

\begin{abstract}
Cardiomyopathy involves changes in the myocardial ultra-structure, hypertrophy, apoptosis, fibrosis and inflammation. Angiotensin II (AngII) stimulates the expression of insulin like-growth factors (IGF-2) and IGF-2 receptor (IGF-2R) in $\mathrm{H} 9 \mathrm{c} 2$ cardiomyoblasts and subsequently leads to apoptosis. Estrogen receptors protect cardiomyocytes from apoptosis and fibrosis. Tanshinone IIA (TSN), a main active ingredient from Danshen, has been shown to protect cardiomyocytes from death caused by different stress signals. Estrogen receptor $\alpha$ (ER) is required for the rapid activation of the IGF-IR signaling cascade. This study aimed to investigate whether TSN protected H9c2 cardiomyocytes from Angll-induced activation of IGF-2R pathway and hypertrophy via ERs. We found that Angll caused the reduction in IGF-1R phosphorylation and the elevation of $\beta$-catenin and IGF-2R levels. This was reversed by increasing doses of TSN and of caspase- 3 and ERK1/2 phosphorylation mediated by ERs. The phytoestrogen significantly attenuated Angll-induced apoptosis and suppressed the subsequent cardiac remodeling effect. Therefore, TSN reduced the Angll-induced activation of $\beta$-catenin and IGF-2R pathways, apoptosis and cardiac remodeling via ERs in $\mathrm{H} 9 \mathrm{c} 2$ cardiomyoblasts.
\end{abstract}

Key words: Angiotensin II; $\beta$-Catenin; Estrogen receptors; H9c2 Cardiomyoblasts; Insulin-like Growth Factor-2 Receptor; Tanshinone IIA.

\section{Introduction}

Cardiac hypertrophy is a normal injury arising in different cardiovascular diseases, including hypertension, myocardial dead tissue, and inborn coronary illness, and is the main cause of heart failure and sudden death in patients with the above maladies. The principal pathological changes in cardiovascular hypertrophy are introduced through the progression of numerous events, including myocardial interstitial cell hypertrophy, myocardial interstitial cell multiplication, and extracellular lattice 
increment of myocardial cells, eventually leading to myocardial rebuilding. IGF-2 shares $47 \%$ homology with insulin [1,2] and plays a role in mammalian postnatal and fetal growth [3-5]. However, its expression drops after birth and goes through a transition during the neonatal stage [4]. IGF-2 was found to behave as a rescuer in a brief coronary occlusion porcine model and in a sheep model with myocardial infarction [6]; however, it was later shown to cause Beckwith-Wiedemann syndrome, prenatal overgrowth, poly hydramnios and fetal and neonatal lethality [7]. IGF-2R binds IGF-2 on the cell surface and to mannose-6-phosphate (M6P)-tagged proteins in the trans-Golgi network [8]. It is a type I trans membrane receptor with a large extracellular domain, a relatively short intracellular tail and a trans membrane domain [9]. The binding ofIGF-2 to IGF-2R causes the phosphorylation of phospholipase- $\beta$ and subsequently apoptosis of H9c2 cardiomyoblasts [10]. In previous studies, AngII was shown to induce the expression of IGF-2 and IGF-2R in cardiomyocytes via MEK and JNK [11]. Subsequently, the binding ofIGF-2 to IGF-2R leads to the activation of phosphatase 2B (PP2A or calcineurin), which dephosphorylates Bad and subsequently results in its translocation to the mitochondria [10]. This results in apoptosis of the cardiomyocytes via mitochondrial outer-membrane permeability. In cardiomyocytes, the expression $\beta$-catenin can be stimulated by various stress signals, such as endothelin-1, pressure overload and phenylephrine, which can stimulate $\beta$-catenin pathway [12]. Estrogen is a steroid hormone, existing in 3 different isoforms, estrone (E1), 17 $\beta$-estradiol (E2) and estriol (E3), among which E2 has the highest biological activity [13]. The hormone binds to its cell surface receptors, estrogen receptors $a$ and $\beta$ (ER $\alpha$ and ER $\beta$ ) [14]. E2 and ERs have been shown to protect cardiomyocytes from apoptosis and fibrosis [15]. Many phytoestrogens, such as genistein, tanshinone IIA and resveratrol, have been shown to exert a protective effect against cardiovascular diseases via the ERs [16-18].

TSN was discovered from Salvia miltiorrhiza Bunge (Danshen) and is used to treat cardiovascular disorders and hepatitis in Asia [19].Phytochemicals from in Danshen, including TSN, exhibit protective effects including antibacterial activity, antioxidative activity, anti-inflammatory activity and anti-cytotoxicity and act as inhibitors of platelet aggregation. In different studies, TSN was shown to protect cardiomyocytes from cellular damages [20-22]. This study aimed to investigate the effects of TSN on estrogen receptors and determine whether it exerts a protective effect against AngII-induced activation of $\beta$-catenin and IGF-2R, apoptosis and cardiac remodeling in cardiomyocytes.

\section{Materials and Methods}

\section{Cell Culture}

H9c2 cardiomyoblasts from American Type Culture Collection (ATCC) (Rockville, MD) were cultured in 10-cm dishes in DMEM (St. Louis, Sigma, $\mathrm{MO}$ ) with $10 \%$ cosmic calf serum (CCS; HyClone, South Logan, UT) in humidified air $\left(5 \% \mathrm{CO}_{2}\right)$ at $37^{\circ} \mathrm{C}$. The medium was replaced every $48 \mathrm{~h}$. The cells were washed with 3 to $5 \mathrm{ml} 1 \times$ Dulbecco's phosphate-buffered saline $(1 \times$ PBS; Gibco, Auckland, New Zealand). The H9c2 cells were administered with AngII (St. Louis,Sigma, MO), ICI 182780 (ICI; ER inhibitor; Tocris Bioscience, Bristol, UK) or TSN (St. Louis, Sigma, MO) with appropriate concentrations.

\section{Immunofluorescence Microscopy}

H9c2 cells were seeded in 12-well plates $\left(1 \times 10^{5}\right.$ cells per well). Twenty-four hours after cell seeding, $10^{-8} \mathrm{M}$ AngII was added, followed by $40 \mu \mathrm{M}$ TSN after $1 \mathrm{~h}$ and then $10^{-6} \mathrm{M} \mathrm{ICI}$ after another $2 \mathrm{~h}$. Twenty-four hours after the administration of ICI, cells were fixed with $4 \%$ paraformaldehyde in $1 \times \mathrm{PBS}$ at RT for $15 \mathrm{~min}$. The cells were permeabilized with $0.1 \%$ Triton X-100 in $0.1 \%$ sodium citrate for $20 \mathrm{~min}$. Non-specific binding of the fixed cells was blocked with $10 \%$ CCS at room temperature (RT) for $1 \mathrm{~h}$ and the cells were incubated with diluted primary antibody solutions in $1 \times \mathrm{PBS}$ for $48 \mathrm{~h}$ at $4^{\circ} \mathrm{C}$. Then, the cells were incubated with Alexa Fluor 488-conjugated donkey anti-goat IgG secondary antibody (Invitrogen Corp., Carlsbad, $\mathrm{CA}$ ) in the dark for $1 \mathrm{~h}$ at $37^{\circ} \mathrm{C}$. Finally, the cells were stained with $1 \mu \mathrm{g} / \mathrm{ml}$ DAPI for 5 min to detect the cell nuclei (blue staining). Fluorescence was visualized using a fluorescence microscope coupled with an image analysis system.

\section{Nuclear and Cytoplasmic Fractionation}

The cells were harvested in PBS and centrifuged at $1,000 \mathrm{~g}$ for $10 \mathrm{~min}$ at $4^{\circ} \mathrm{C}$. After carefully aspirating the supernatant, the cells were resuspended in $200 \mu \mathrm{L}$ ice-cold BUFFER-I (10 mM Hepes (pH 8.0), $1.5 \mathrm{mM}$ $\mathrm{MgCl}_{2}, 10 \mathrm{mM} \mathrm{KCl}, 1 \mathrm{mM}$ dithiothreitol, and proteinase inhibitor cocktail (Roche Molecular Biochemicals)) and incubated for $15 \mathrm{~min}$ on ice to allow the cells to be lysed, followed by adding $20 \mu \mathrm{L}$ IGEPAL-CA630. After vigorously vortexing for $10 \mathrm{~s}$ and centrifuging at $12,000 \mathrm{~g}$ for $5 \mathrm{~min}$ at $4{ }^{\circ} \mathrm{C}$, the supernatant (cytoplasmic fraction) was carefully aspirated and the pellet was resuspended with ice-cold BUFFER-II (20 mM Hepes ( $\mathrm{pH} 8.0), 1.5 \mathrm{mM}$ $\mathrm{MgCl}_{2}, 25 \%$ glycerol, $420 \mathrm{mM} \mathrm{NaCl}, 0.2 \mathrm{mM}$ EDTA, 
$1 \mathrm{mM}$ dithiothreitol and proteinase inhibitor cocktail (Roche Molecular Biochemicals)) and vigorously vortexed. After vortexing, the suspension was placed on ice for $30 \mathrm{~min}$ before centrifuging at $15,000 \mathrm{~g}$ for $15 \mathrm{~min}$ at $4^{\circ} \mathrm{C}$. The supernatant (nuclear extracts) was stored in aliquots at $-80^{\circ} \mathrm{C}$. These samples contained the nuclear proteins. Protein concentration in each sample was determined by the Lowry assay, and Western blot analysis was conducted in order to determine the protein expression.

\section{TUNEL Assay}

H9c2 cells were seeded in 12-well plates $\left(1 \times 10^{5}\right.$ cells per well) containing DMEM(10\% CCS) to $80-90 \%$ confluency and incubated for $24 \mathrm{~h}$ in humidified air with $5 \% \mathrm{CO}_{2}$ at $37^{\circ} \mathrm{C}$. Twenty-four hours after cell seeding, 10-8 M AngII was added, followed by $40 \mu \mathrm{M}$ TSN after $1 \mathrm{~h}$ and then $10^{-6} \mathrm{M}$ ICI after another $2 \mathrm{~h}$. Twenty-four hours after the administration of ICI, each well was washed with $1 \times$ PBS $(1 \mathrm{ml} /$ well $)$ and then incubated with the fixative $(1 \mathrm{ml} /$ well $)(4 \%$ paraformaldehyde in $1 \times \mathrm{PBS})$ at $\mathrm{RT}$ for $1 \mathrm{~h}$. The blocking buffer $\left(3 \% \mathrm{H}_{2} \mathrm{O}_{2}\right.$ in $100 \%$ methanol) was added ( $1 \mathrm{ml} /$ well) and the plate was incubated for 10 min at RT. The permeabilization solution $(0.1 \%$ Triton $\mathrm{X}-100$ in $0.1 \%$ sodium citrate) was added (0.5 $\mathrm{mL} /$ well) and the 12-well plate was placed on ice for 2 min without shaking. The diluted 10× TUNEL reagent (Roche Diagnostics GmbH, Mannheim,Germany) was added (200-250 $\mu \mathrm{L} /$ well) and the plate was placed in a humidified incubator at $37^{\circ} \mathrm{C}$ in the dark for $1 \mathrm{~h}$ for the reagent to react with cell nuclei. Diluted 10000x DAPI was added $(200 \mu \mathrm{L} /$ well $)$ and the plate was covered with tin foil and rested for $25 \mathrm{~min}$. Finally, the cells were observed under fluorescence microscope. The number of TUNEL-positive cardiac myocytes and the number of apoptotic bodies were determined by counting $3 \times 10^{5}$ cardiac myocytes. All morphometric measurements were performed by at least two independent individuals in a blinded manner.

\section{Western Blot Analysis}

H9c2 cells were seeded in 10-cm culture plates (1 $\times 10^{5}$ cells per well) containing DMEM $(10 \%$ CCS) to $80-90 \%$ confluency and incubated for $24 \mathrm{~h}$ in humidified air with $5 \% \mathrm{CO} 2$ at $37^{\circ} \mathrm{C}$. Twenty-four hours after cell seeding, $10^{-8} \mathrm{M}$ AngII was added,

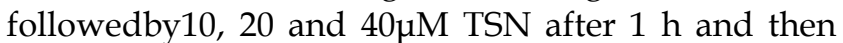
$10^{-6} \mathrm{M}$ ICI after another $2 \mathrm{~h}$. Twenty-four hours after the administration of ICI, each plate was washed twice with $3-4 \mathrm{ml} 1 \times \mathrm{PBS}$ and the remaining fluid in each plate was discarded. Then, $100 \mu \mathrm{L}$ cell lysis buffer (50 mM Tris-base ( $\mathrm{pH} 7.5$ ), $0.5 \mathrm{M} \mathrm{NaCl}, 1 \mathrm{mM}$ EDTA (pH 8.0), $1 \mathrm{mM} \beta$-mercaptoethanol, $1 \%$ NP-40, $1 \%$ glycerol and protease inhibitor cocktail tablets) was added to lyse cells in each plate. The cells were scraped down and collected in appropriate $1.5-\mathrm{ml}$ micro centrifuge tubes on ice, which were then vortexed three times, once every $10 \mathrm{~min}$ and centrifuged for $20 \mathrm{~min}$ at $12000 \mathrm{rpm}$ at $4^{\circ} \mathrm{C}$. The supernatants were transferred to another set of $1.5-\mathrm{ml}$ micro centrifuge tubes. These were the total protein samples. The protein concentration in each sample was determined by the Lowry assay, and Western blot analysis was conducted in order to determine the protein expression.

\section{Statistical Analysis}

Each sample was analyzed based on the results from experiments that were repeated at least three times, and Sigma Plot 10.0 software and ANOVA was used to analyze the numerical data. The values were expressed as the means $\pm \mathrm{SD}$ and statistical significance was set at $\mathrm{P}<0.05$. The statistical data significant TSN treatment group compared to ANGII.

\section{Results}

\section{TSN Up-Regulated the Expression of Endogenous ERs and Survival Pathway while Reducing AngII-Induced $\beta$-Catenin and IGF-2 Pathways in $\mathrm{H} 9 \mathrm{c} 2$ Cardiomyoblasts in a Dose-Dependent Manner}

To determine whether TSN was able to increase the expression of ERs and survival proteins and reduce $\beta$-catenin and IGF-2 pathways under the influence of AngII in the H9c2 cells, effective doses of the AngII were tested. AngII significantly increased the levels of $\beta$-catenin, IGF-2R, LEF-1, NFAT-c3 p-GATA-4, cleaved caspase-3 protein and reduced the level of p-IGF-1R protein (Fig. 1A), the difference is statistically significant (Fig 1B). In previous publications from the PI lab, $10^{-7} \mathrm{M}$ and $10^{-8} \mathrm{M}$ doses of AngII were shown to induce significant increases in the apoptosis of H9c2 cells at the 24h time point. Therefore, the $10^{-8} \mathrm{M}$ dose of AngII was chosen for subsequent experiments. The administration of AngII alone reduced ERa, ER $\beta$, IGF-1R and p-IGF-1R and elevated $\beta$-catenin, $\mathrm{p}$-ERK1/2, IGF-2R and cleaved caspase-3, (Fig. 1C). The administration of $40 \mu \mathrm{M}$ TSN up-regulated the expression of ERs and cell survival pathway, and decreased AngII-induced $\beta$-catenin, p-ERK1/2, IGF-2R and cleaved caspase-3 in the H9c2 cells. Therefore, TSN was able to up-regulate ERs and IGF-1R/Akt survival pathway and reduce the AngII-induced activation of $\beta$-catenin and IGF-2 pathways in the $\mathrm{H} 9 \mathrm{c} 2$ cardiomyoblasts in a dose-dependent manner and the difference is statistically significant showed Fig 1D. 
A.

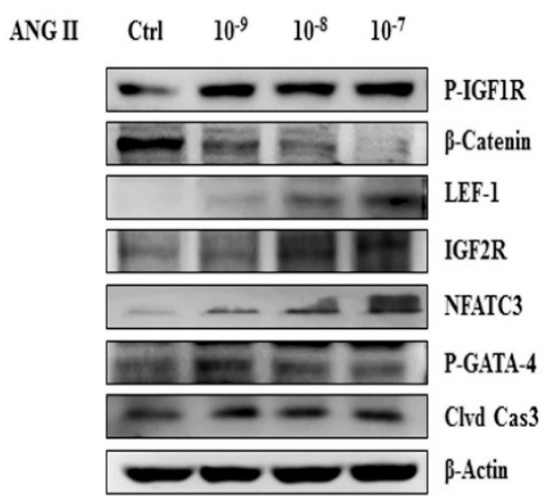

B.
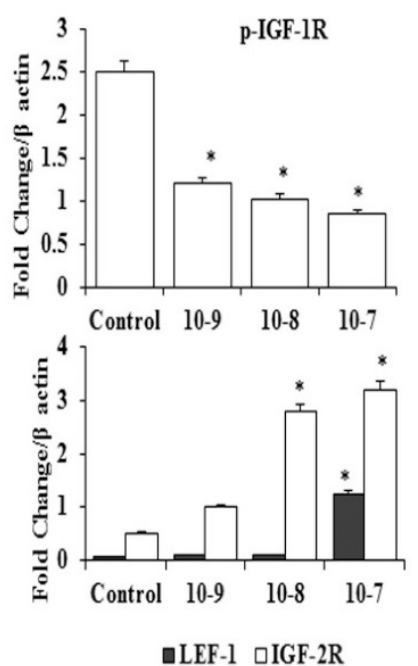
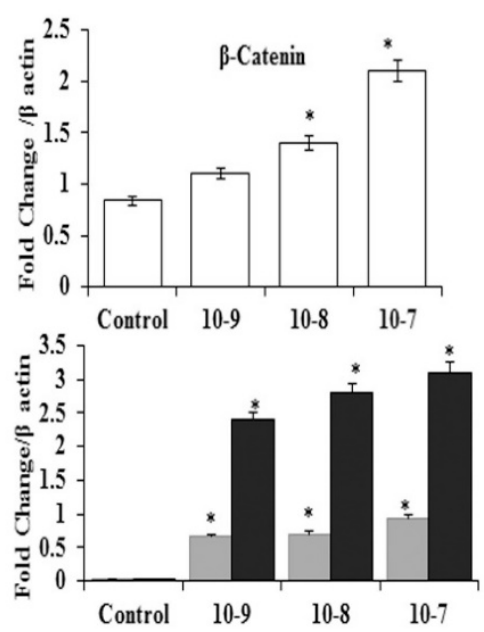

-P-GATA-4 aClvd-Caspase3
C

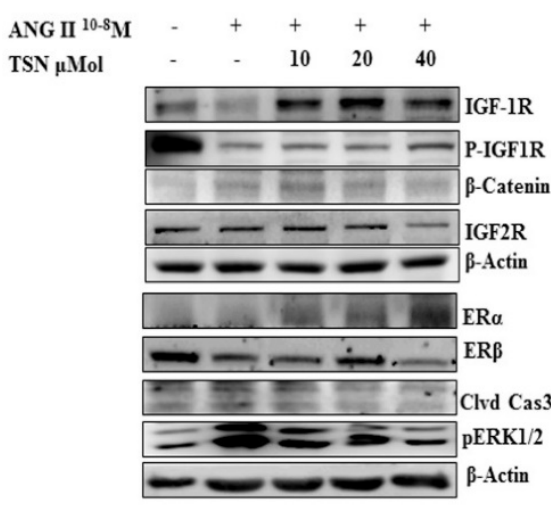

D

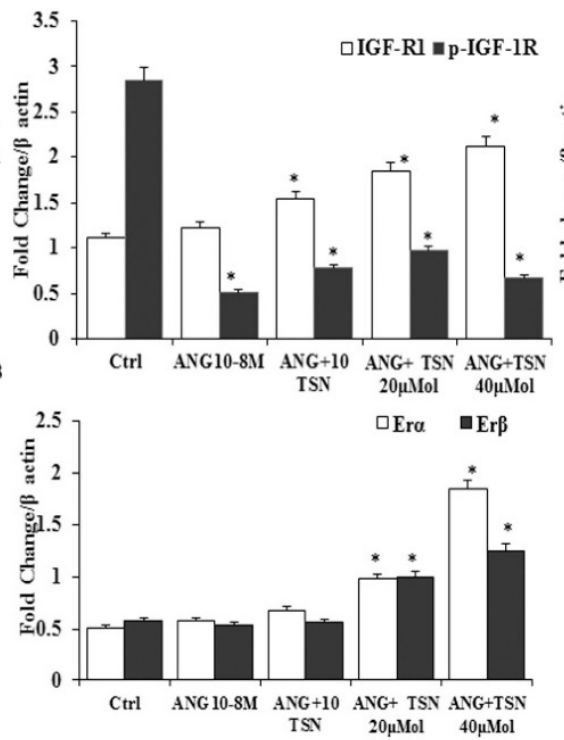

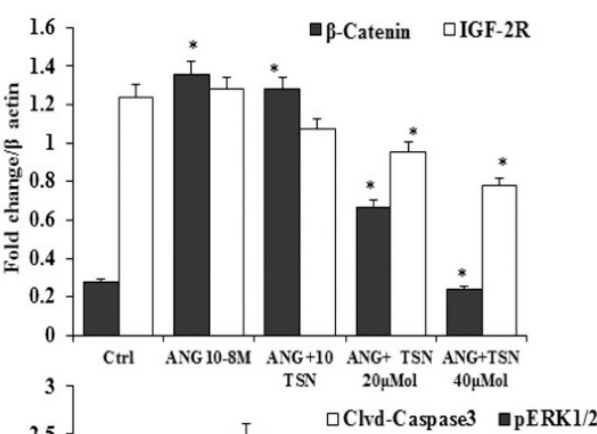

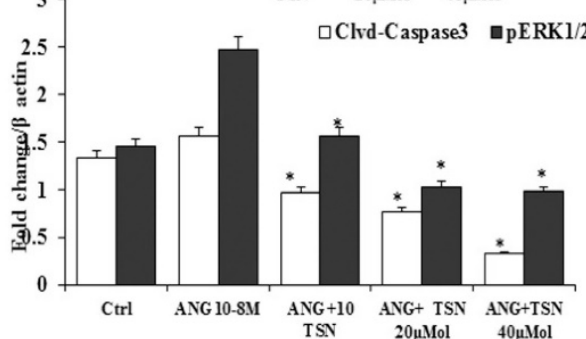

Figure 1. TSN suppressed the Angll-induced activation of $\beta$-catenin and IGF-2pathways and increased the expression of endogenous ERs and survival pathway in $\mathrm{H} 9 \mathrm{c} 2$ cardiomyoblasts in a dose-dependent manner; all the experiments were repeated at least three times. (A) Twenty-four hours after seeding the $\mathrm{H} 9 \mathrm{c} 2 \mathrm{cells}$ in 10 -cm culture plates, different doses of Angll were added. Western blot analysis was conducted $24 \mathrm{~h}$ after the administration of Angll. (B) The difference is statistically significant. (C) Twenty-four hours after seeding the $\mathrm{H} 9 \mathrm{c} 2$ cells in 10-cm culture plates, 10-8 M Angll was added, followed by different doses of TSN. Western blot analysis was conducted $24 \mathrm{~h}$ after the administration of TSN. (D) Difference is statistically significant. Data are expressed as the fold change relative to the control and presented as the mean \pm SD, representing the results of three independent experiments $(n=3, * p<0.05$ was considered significant).

\section{AngII Increased the Expression and Nuclear Localization of $\beta$-Catenin, which were reversed by TSN via the Activation of ERs}

In different studies, AngII was found to activate the $\beta$-catenin pathway in a mouse model and in podocytes [23]. Hence, the possibility of induction of $\beta$-catenin by AngII in the $\mathrm{H} 9 \mathrm{c} 2$ was determined first. Then, effect of TSN on the activity of the $\beta$-catenin pathway was investigated. AngII at $10^{-8} \mathrm{M}$ alone increased $\beta$-catenin and LEF-1 and reduced ERa and
ER $\beta$ (Fig. 2A) and the difference is statistically significant (2B). In contrast, $40 \mu \mathrm{M}$ TSN decreased AngII-induced $\beta$-catenin and LEF-1 and increased ERa and ER $\beta$, and this was reversed by $10^{-6} \mathrm{M}$ ICI. Moreover, $10^{-8} \mathrm{M}$ AngII also led to an increase in the nuclear localization of $\beta$-catenin (Fig. $2 \mathrm{C}$ and 2E). However, this was down-regulated by the addition of $40 \mu \mathrm{M}$ TSN. Nevertheless, the addition of $10^{-6} \mathrm{M} \mathrm{ICI}$ restored nuclear level of $\beta$-catenin. The difference is statistically significant showed in figure 2D. Therefore, TSN was able to attenuate AngII-induced 
activation of $\beta$-catenin pathway via ERs in the H9c2 cardiomyoblasts.

\section{TSN Reduced Angll-Induced Apoptosis and Promoted Survival in H9c2 Cardiomyocytes}

In other studies, AngII was found to cause apoptosis in cardiomyocytes [24]. TSN was found to protect the cardiomyocytes from apoptosis [25]. To investigate the effect of TSN on AngII-induced apoptosis, Western blot analysis was performed.
Administration of $10^{-8} \mathrm{M}$ AngII alone resulted in the significant increase in the levels of apoptotic proteins, cleaved caspase-3, and a sharp reduction in survival pathway proteins (Fig. 3A) difference is statistically significant as showed in figure $3 \mathrm{~B}$. This was counteracted by the addition of $40 \mu \mathrm{M}$ TSN. However, the anti-apoptotic effect of the phytoestrogen was reversed by the addition of $10^{-6} \mathrm{M}$ ICI. Furthermore, AngII alone caused a significant increase in the total number of TUNEL-positive cells (Fig. 3C). TSN A

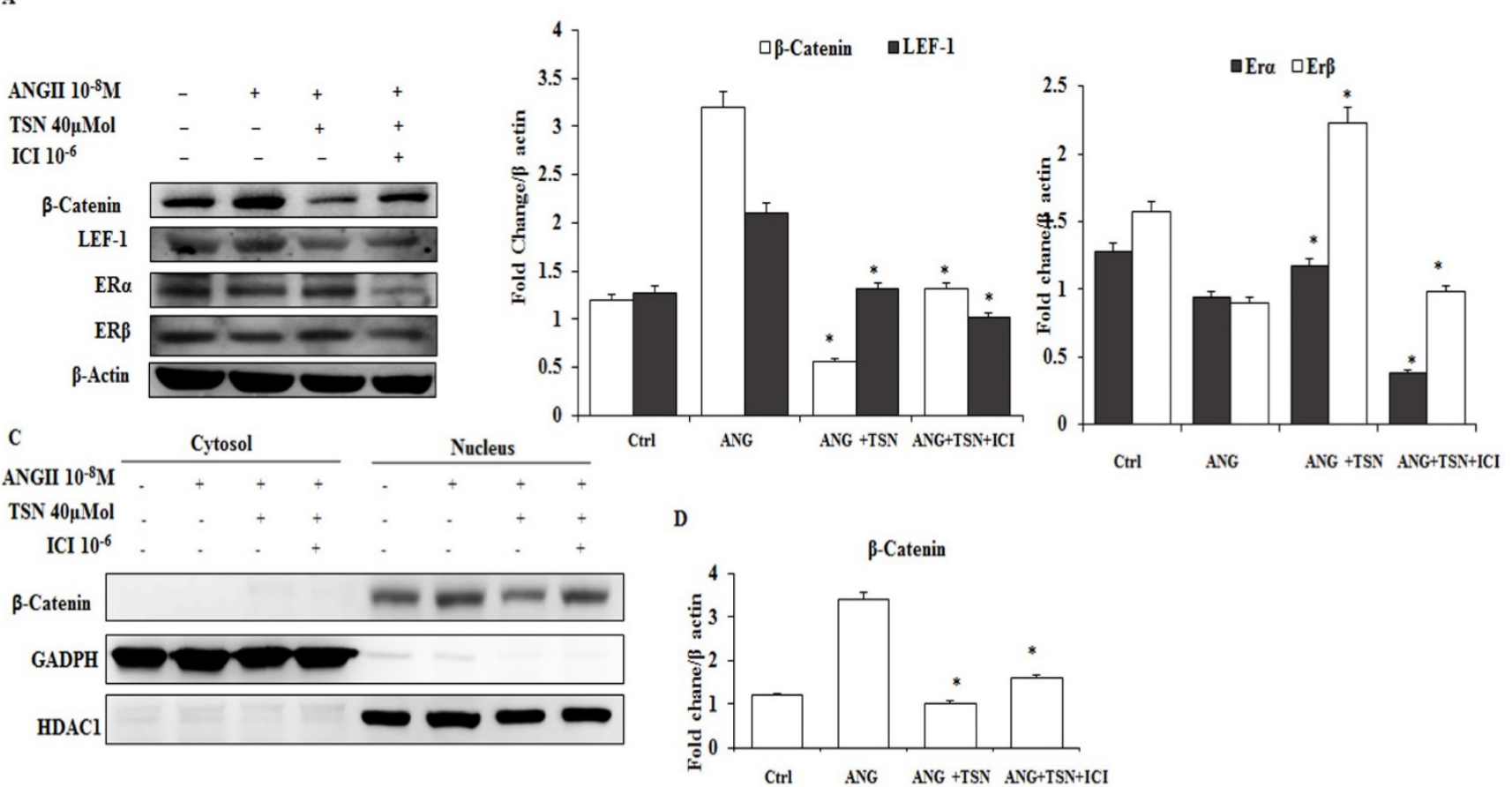

E
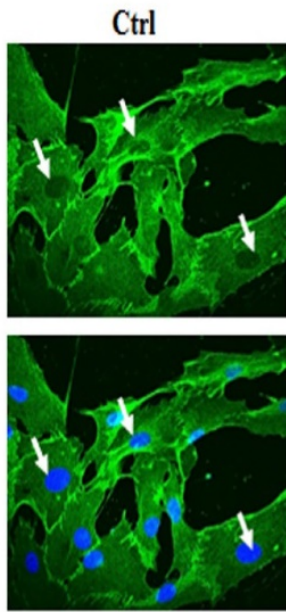

Green: $\beta$-Catenin Blue: DAPI

Figure 2. TSN reduced Angll-induced $\beta$-catenin expression and nuclear localization through ERs; all the experiments were repeated at least three times. (A) Twenty-four hours after seeding the $\mathrm{H} 9 \mathrm{c} 2$ cells in $10-\mathrm{cm}$ culture plates, 10-8 M Angll was added, followed by $40 \mu \mathrm{M}$ TSN and $10^{-6} \mathrm{MICl}$. Western blot analysis was conducted $24 \mathrm{~h}$ after the administration of ICl. (B) fold change were calculated and are shown. (C) Twenty-four hours after seeding the $\mathrm{H} 9 \mathrm{c} 2$ cells in $10-\mathrm{cm}$ culture plates, $10^{-8} \mathrm{M}$ Angll was added, followed by $40 \mu \mathrm{MTSN}$ and $10^{-6} \mathrm{M} \mathrm{ICl}$. The nuclear and cytoplasmic fractions were separated $24 \mathrm{~h}$ after the administration of ICI. (D) Difference is statistically significant. (E) Twenty-four hours after seeding the $\mathrm{H} 9 \mathrm{c} 2$ cells in $10-\mathrm{cm}$ culture plates, 10-8 M Angll was added, followed by $40 \mu \mathrm{M}$ TSN and $10^{-6} \mathrm{M} \mathrm{ICl}$. Confocal microscopy was conducted $24 \mathrm{~h}$ after the administration of $\mathrm{ICI}$. Data are expressed as the fold change relative to the control and presented as the mean \pm SD, representing the results of three independent experiments $(\mathrm{n}=3, * p<0.05$ was considered significant). 
treatment reduced the number of TUNEL-positive $\mathrm{H} 9 \mathrm{c} 2$ cells and the addition of $10^{-6} \mathrm{M} \mathrm{ICI}$ reversed this effect. Therefore, TSN protected the H9c2 cells from AngII-induced apoptosis through ERs.

\section{TSN Attenuated AngII-Induced Fibrosis in H9c2 Cardiomyoblasts via ERs}

AngII has been shown to induce fibrosis [26]. To investigate effect of TSN on AngII-induced fibrosis, Western blot analysis was performed. AngII up-regulated the levels of MMP-9, MMP-2, TGF- $\beta 1$, p-Smad2/3, SP-1 and CTGF proteins and decreased the expression of TIMP-1and TIMP-2 (Fig. 4A). TSN, on the other hand, reduced the AngII-induced protein expression of fibrosis markers at $40 \mu \mathrm{M}$ and $10^{-6} \mathrm{M}$ ICI reversed this situation. The difference is statistically significant showed in figure 4B.

A

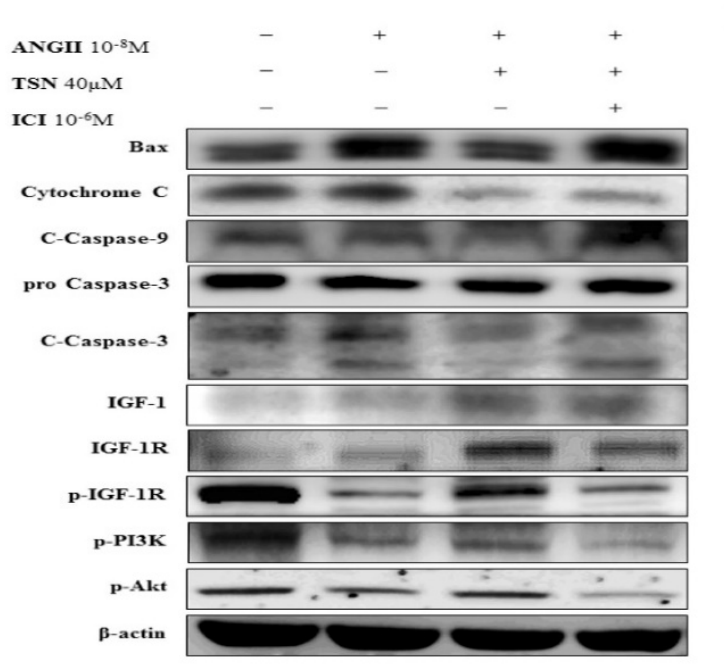

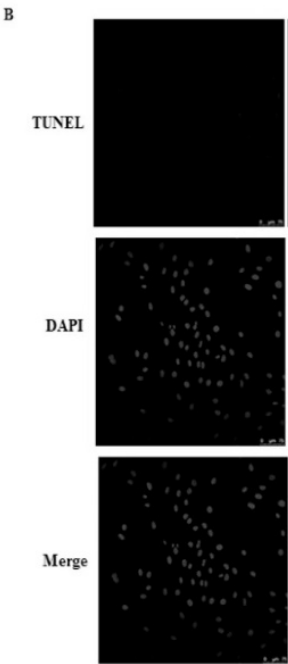

Ctrl
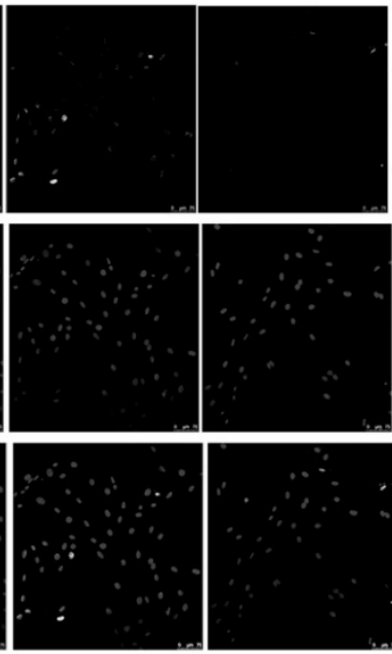

ANGII

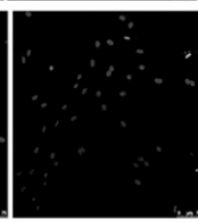

ANG + TSN
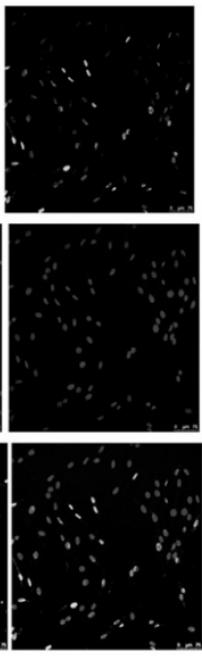

ANG+TSN+ICI
C

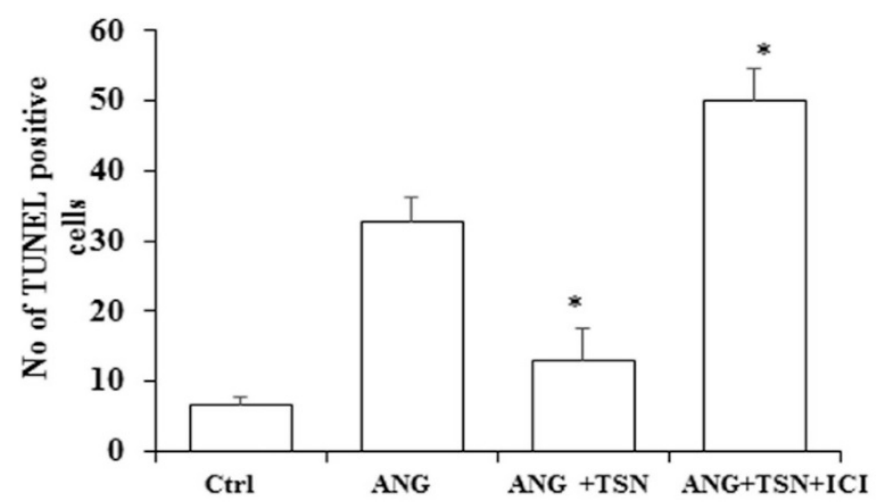

Figure 3. TSN reduced Angll-induced apoptosis and promoted survival via estrogen receptors in $\mathrm{H} 9 \mathrm{c} 2$ cardiocytes. (A) Twenty-four hours after seeding the $\mathrm{H} 9 \mathrm{c} 2$ cells in 10 -cm

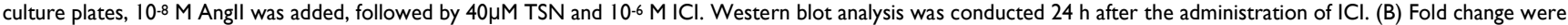
calculated and are shown. (C) Twenty-four hours after seeding the H9c2 cells in 10-cm culture plates, 10-8M Angll was added, followed by $40 \mu \mathrm{M}$ TSN and 10-6 M ICI. TUNEL staining was conducted $24 \mathrm{~h}$ after the administration of $\mathrm{ICl}(400 \mathrm{X}$ magnification). Data are expressed as the fold change relative to the control and presented as the mean $\pm \mathrm{SD}$, representing the results of three independent experiments $(n=3, * p<0.05$ was considered significant). 
death caused by different stress signals [18]. AngII was previously found to be capable of inducing the expression of IGF-2 andIGF-2R via MEK and JNK, resulting in the apoptosis of cardiomyocytes [11]. In this particular study, AngII was shown to reduce the activities of the cell survival pathway and ER signaling while promoting the expression of the $\beta$-catenin pathway and IGF-2R, ERK1/2 phosphorylation, NFAT-c3 activation and apoptosis in H9c2cardiomyoblasts. However, the addition of TSN promoted IGF-1R phosphorylation and the activation of estrogen receptors and down-regulated the expression of $\beta$-catenin andIGF-2R and reduced the activation of caspase-3 and phosphorylation of ERK1/2. In different study, AngII was shown to not only trigger the expression of IGF-2 and IGF-2R [31] but also cause cardiac hypertrophy [32]. In addition, IGF-2R is also able of inducing cardiac hypertrophy [18]. In this study, AngII stimulated the activities of MAPKs (ERK1/2, JNK and p38) and the expression of IGF-2R and hypertrophic proteins. In other words, AngII caused an IGF-2R-induced hypertrophic response in $\mathrm{H} 9 \mathrm{c} 2$ cardiomyoblasts. TSN significantly attenuated the phosphorylation of MAPKs andGATA- 4 and reduced the protein levels of IGF-2R and hypertrophic markers. These effects were reversed by ICI, an inhibitor of the ERs. Therefore, the phytochemical TSN signaled through the ERs to lessen AngII-induced hypertrophy in H9c2 cells.

In previous studies, AngII was found to induce the expression of $\beta$-catenin to cause cellular damages [33]. In the present study, the increase in the levels of $\beta$-catenin and LEF-1 proteins and the nuclear localization of $\beta$-catenin were results of the AngII treatment, which also caused a reduction in ERa and ER $\beta$. TSN, in contrast, exhibited inhibitory effects on $\beta$-catenin activation and restored the estrogen receptors in the $\mathrm{H} 9 \mathrm{c} 2$ cells. In other words, TSN suppressed AngII-induced $\beta$-catenin signaling through ERs in $\mathrm{H} 9 \mathrm{c} 2$ cardiomyoblasts. This phenomenon was observed in another study where TSN exerted a protective effect against AngII-induced damages inH9c2 cells through the activation of ERs [18]. In this study, AngII alone caused a significant increase in the levels of Bax, cytochrome c, caspase- 9 andcaspase- 3 proteins in $\mathrm{H} 9 \mathrm{c} 2$ cells. TSN not only decreased AngII-triggered apoptosis but also up-regulated the IGF-1 survival pathway. However, this event was blocked by the use of ICI. Similarly, TSN reduced Leu27IGF-2-induced apoptosis in cardiomyocytes through the estrogen receptors [18]. In other studies, the activation of ERs was shown to down-regulated apoptosis in cardiomyocyte caused by different stress stimuli. AngII was previously shown to causes cardiac fibrosis [34]. Furthermore, AngII was also found to stimulate inflammation of the heart [35]. In this particular study, the administration of AngII alone resulted in an increase in the expressions of fibrosis markers and inflammation to some degree. However, these were reduced by TSN
A

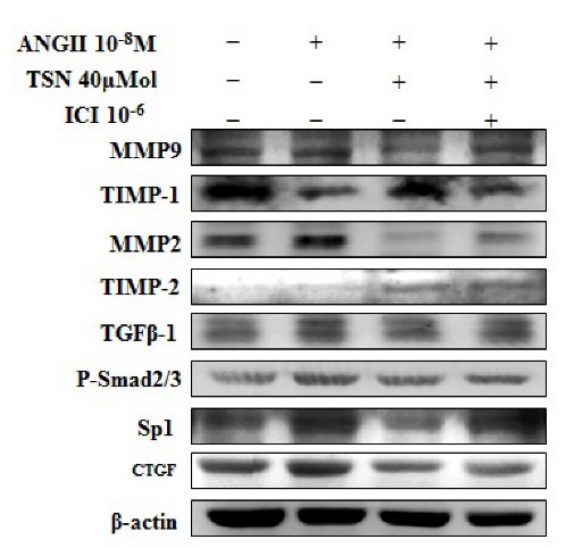

B
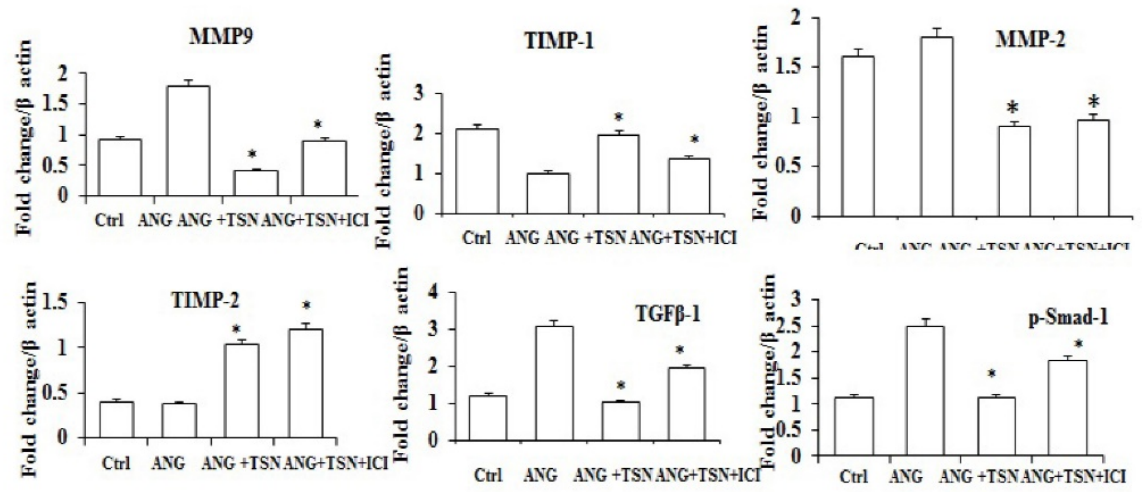
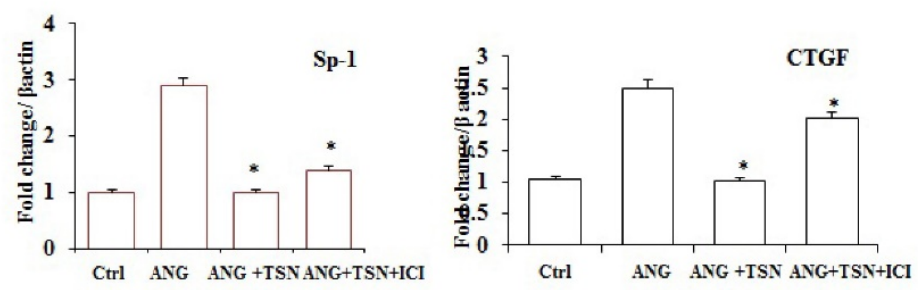

Figure 4. TSN reduced Angll-induced fibrosis via ERs in $\mathrm{H} 9 \mathrm{c} 2$ cardiomyocytes. (A) Twenty-four hours after seeding the H9c2 cells in 10-cm culture plates, 10-8 M Angll was added, followed by $40 \mu \mathrm{M}$ TSN and 10-6 M ICl. Western blot analysis was conducted $24 \mathrm{~h}$ after the administration of ICl. (B) Fold change were calculated and are shown. 
and restored by ICI. Similarly, estrogen receptors were shown to prevent or suppress cardiac fibrosis [36] and inflammation [37].

In conclusion, AngII was found to significantly increase the expression and nuclear localization of $\beta$-catenin and to increase the expression of IGF-2R, apoptotic proteins and fibrosis while increasing the localization of the IGF-2R molecules to the cell membrane. These effects were sharply reduced by TSN via estrogen receptors, as they were activated by the phytoestrogen. Therefore, tanshinone IIA attenuates $\beta$-catenin and IGF-2R pathways and reduces subsequent apoptosis and remodeling while increasing survival proteins in $\mathrm{H} 9 \mathrm{c} 2$ cardiomyoblasts.

\section{Acknowledgments}

This study was supported in part by the Taiwan Ministry of Health and Welfare Clinical Trial and Research Center of Excellence (MOHW106-TDUB-212- 113004).

\section{Competing Interests}

The authors have declared that no competing interest exists.

\section{References}

1. Park GH, Buetow DE. Genes for insulin-like growth factors I and II are expressed in senescent rat tissues. Gerontology. 1991; 37: 310-6.

2. Sklar MM, Thomas CL, Municchi G, Roberts CT, Jr., LeRoith D, Kiess W, et al. Developmental expression of rat insulin-like growth factor-II/mannose 6-phosphate receptor messenger ribonucleic acid. Endocrinology. 1992; 130: 3484-91.

3. Brown AL, Graham DE, Nissley SP, Hill DJ, Strain AJ, Rechler MM. Developmental regulation of insulin-like growth factor II mRNA in different rat tissues. The Journal of biological chemistry. 1986; 261: 13144-50.

4. Engelmann GL, Boehm KD, Haskell JF, Khairallah PA, Ilan J. Insulin-like growth factors and neonatal cardiomyocyte development: ventricular gene expression and membrane receptor variations in normotensive and hypertensive rats. Molecular and cellular endocrinology. 1989; 63: 1-14

5. Ghosh P, Dahms NM, Kornfeld S. Mannose 6-phosphate receptors: new twists in the tale. Nature reviews Molecular cell biology. 2003; 4: 202-12.

6. Matthews KG, Devlin GP, Conaglen JV, Stuart SP, Mervyn Aitken W, Bass JJ. Changes in IGFs in cardiac tissue following myocardial infarction. The Journal of endocrinology. 1999; 163: 433-45.

7. Sun FL, Dean WL, Kelsey G, Allen ND, Reik W. Transactivation of Igf2 in a mouse model of Beckwith-Wiedemann syndrome. Nature. 1997; 389: 809-15.

8. Frago S, Nicholls RD, Strickland M, Hughes J, Williams C, Garner L, et al. Functional evolution of IGF2:IGF2R domain 11 binding generates novel structural interactions and a specific IGF2 antagonist. Proceedings of the National Academy of Sciences of the United States of America. 2016; 113: E2766-75

9. Martin-Kleiner I, Gall Troselj K. Mannose-6-phosphate/insulin-like growth factor 2 receptor (M6P/IGF2R) in carcinogenesis. Cancer letters. 2010; 289: $11-22$

10. Chen RJ, Wu HC, Chang MH, Lai CH, Tien YC, Hwang JM, et al. Leu27IGF2 plays an opposite role to IGF1 to induce H9c2 cardiomyoblast cell apoptosis via Galphaq signaling. Journal of molecular endocrinology. 2009; 43: 221-30.

11. Lee SD, Chu CH, Huang EJ, Lu MC, Liu JY, Liu CJ, et al. Roles of insulin-like growth factor II in cardiomyoblast apoptosis and in hypertensive rat heart with abdominal aorta ligation. American journal of physiology Endocrinology and metabolism. 2006; 291: E306-14

12. Hannenhalli S, Putt ME, Gilmore JM, Wang J, Parmacek MS, Epstein JA, et al. Transcriptional genomics associates FOX transcription factors with human heart failure. Circulation. 2006; 114: 1269-76.

13. Gruber CJ, Tschugguel W, Schneeberger C, Huber JC. Production and actions of estrogens. The New England journal of medicine. 2002; 346: 340-52.

14. Li X, Huang J, Yi P, Bambara RA, Hilf R, Muyan M. Single-chain estrogen receptors (ERs) reveal that the ERalpha/beta heterodimer emulates functions of the ERalpha dimer in genomic estrogen signaling pathways. Molecular and cellular biology. 2004; 24: 7681-94.
15. Mahmoodzadeh S, Leber I, Zhang X, Jaisser F, Messaoudi S, Morano I, et al. Cardiomyocyte-specific Estrogen Receptor Alpha Increases Angiogenesis, Lymphangiogenesis and Reduces Fibrosis in the Female Mouse Heart Post-Myocardial Infarction. Journal of cell science \& therapy. 2014; 5: 153

16. Levenson AS, Gehm BD, Pearce ST, Horiguchi J, Simons LA, Ward JE, 3rd, et al. Resveratrol acts as an estrogen receptor (ER) agonist in breast cancer cells stably transfected with ER alpha. International journal of cancer. 2003; 104: 587-96.

17. Kim JH, Kim YJ. Effects of genistein in combination with conjugated estrogens on endometrial hyperplasia and metabolic dysfunction in ovariectomized mice. Endocrine journal. 2015; 62: 531-42.

18. Weng YS, Wang HF, Pai PY, Jong GP, Lai CH, Chung LC, et al. Tanshinone IIA Prevents Leu27IGF-II-Induced Cardiomyocyte Hypertrophy Mediated by Estrogen Receptor and Subsequent Akt Activation. The American journal of Chinese medicine. 2015; 43: 1567-91.

19. Lee CY, Sher HF, Chen HW, Liu CC, Chen CH, Lin CS, et al. Anticancer effects of tanshinone I in human non-small cell lung cancer. Molecular cancer therapeutics. 2008; 7: 3527-38.

20. Mao S, Li W, Qa'aty N, Vincent M, Zhang M, Hinek A. Tanshinone IIA inhibits angiotensin II induced extracellular matrix remodeling in human cardiac fibroblasts--Implications for treatment of pathologic cardiac remodeling. International journal of cardiology. 2016; 202: 110-7.

21. Luo YX, Tang X, An XZ, Xie XM, Chen XF, Zhao X, et al. Sirt4 accelerates Ang II-induced pathological cardiac hypertrophy by inhibiting manganese superoxide dismutase activity. European heart journal. 2016.

22. Zhou L, Zhou J, Liu Y. [Effect of tanshinone II A on the expressions of NeuN, GFAP and CD11b in Abeta1-42; induced newborn rat hippocampal slices in vitrol. Xi bao yu fen zi mian yi xue za zhi $=$ Chinese journal of cellular and molecular immunology. 2013; 29: 1150-4.

23. Fujishima Y, Maeda N, Matsuda K, Komura N, Hirata A, Mori T, et al. Effect of adiponectin on cardiac beta-catenin signaling pathway under angiotensin II infusion. Biochemical and biophysical research communications. 2014; 444: 224-9.

24. Huang CY, Kuo WW, Yeh YL, Ho TJ, Lin JY, Lin DY, et al. ANG II promotes IGF-IIR expression and cardiomyocyte apoptosis by inhibiting HSF1 via JNK activation and SIRT1 degradation. Cell death and differentiation. 2014; 21: 1262-74.

25. Yang R, Liu A, Ma X, Li L, Su D, Liu J. Sodium tanshinone IIA sulfonate protects cardiomyocytes against oxidative stress-mediated apoptosis through inhibiting JNK activation. Journal of cardiovascular pharmacology. 2008; 51: 396-401.

26. Lijnen PJ, Petrov VV, Fagard RH. Induction of cardiac fibrosis by angiotensin II. Methods and findings in experimental and clinical pharmacology. 2000; 22: 709-23.

27. Soltysinska E, Olesen SP, Osadchii OE. Myocardial structural, contractile and electrophysiological changes in the guinea-pig heart failure model induced by chronic sympathetic activation. Experimental physiology. 2011; 96: 647-63.

28. Distefano G, Sciacca P. Molecular pathogenesis of myocardial remodeling and new potential therapeutic targets in chronic heart failure. Italian journal of pediatrics. 2012; 38: 41

29. Chu CH, Tzang BS, Chen LM, Liu CJ, Tsai FJ, Tsai CH, et al. Activation of insulin-like growth factor II receptor induces mitochondrial-dependent apoptosis through $\mathrm{G}(\mathrm{alpha}) \mathrm{q}$ and downstream calcineurin signaling in myocardial cells. Endocrinology. 2009; 150: 2723-31.

30. Shen $T$, Ding $L$, Ruan $Y$, Qin $W$, Lin $Y, X_{i} C$ et al SIRT1 functions as an important regulator of estrogen-mediated cardiomyocyte protection in angiotensin II-induced heart hypertrophy. Oxidative medicine and cellular longevity. 2014; 2014: 713894.

31. Kuo WW, Liu CJ, Chen LM, Wu CH, Chu CH, Liu JY, et al. Cardiomyoblast apoptosis induced by insulin-like growth factor (IGF)-I resistance is IGF-II dependent and synergistically enhanced by angiotensin II. Apoptosis : an international journal on programmed cell death. 2006; 11: 1075-89.

32. Kagiyama S, Eguchi S, Frank GD, Inagami T, Zhang YC, Phillips MI. Angiotensin II-induced cardiac hypertrophy and hypertension are attenuated by epidermal growth factor receptor antisense. Circulation. 2002; 106: 909-12

33. Jiang L, Xu L, Song Y, Li J, Mao J, Zhao AZ, et al. Calmodulin-dependent protein kinase II/cAMP response element-binding protein/Wnt/beta-catenin signaling cascade regulates angiotensin II-induced podocyte injury and albuminuria. The Journal of biological chemistry. 2013; 288: 23368-79.

34. Qi G, Jia L, Li Y, Bian Y, Cheng J, Li H, et al. Angiotensin II infusion-induced inflammation, monocytic fibroblast precursor infiltration, and cardiac fibrosis are pressure dependent. Cardiovascular toxicology. 2011; 11: 157-67.

35. Sopel MJ, Rosin NL, Lee TD, Legare JF. Myocardial fibrosis in response to Angiotensin II is preceded by the recruitment of mesenchymal progenitor cells. Laboratory investigation; a journal of technical methods and pathology. 2011; 91: 565-78

36. Zimmerman MA, Budish RA, Kashyap S, Lindsey SH. GPER-novel membrane oestrogen receptor. Clinical science. 2016; 130: 1005-16.

37. Xing $\mathrm{D}$, Feng $\mathrm{W}$, Miller AP, Weathington $\mathrm{NM}$, Chen $\mathrm{YF}$, Novak $\mathrm{L}$, et al Estrogen modulates TNF-alpha-induced inflammatory responses in rat aortic smooth muscle cells through estrogen receptor-beta activation. American journal of physiology Heart and circulatory physiology. 2007; 292: H2607-12. 